\title{
STRATEGI REPRODUKSI IKAN TERBANG (EXOCOETIDAE) DAN KAITANNYA DENGAN FAKTOR OSEANOGRAFI DI PERAIRAN INDONESIA
}

\author{
Augy Syahailatua'), Syamsu Alam Ali2), dan Petrus Makatipu ${ }^{3)}$ \\ 1) Peneliti pada Pusat Penelitian Oseanografi-Lembaga IImu Pengetahuan Indonesia, Ancol-Jakarta \\ 2) Peneliti pada Fakultas IImu Kelautan dan Perikanan-Universitas Hasanuddin, Makassar-Sulawesi Selatan \\ 3) Peneliti pada UPT Konservasi Biota Laut-Lembaga IImu Pengetahuan Indonesia, Tandurusa-Bitung \\ Teregristrasi I tanggal: 30 Januari 2008; Diterima setelah perbaikan tanggal: 15 Agustus 2008; \\ Disetujui terbit tanggal: 1 September 2008
}

\begin{abstract}
ABSTRAK
Ikan terbang (Excoetidae) memiliki strategi reproduksi yang diduga terkait dengan kondisi lingkungan perairan laut, seperti suhu, salinitas, angin, curah hujan, dan radiasi matahari. Penelitian dilakukan untuk 3 jenis ikan terbang (Hirundichthys oxycephalus, Cheilopogon cyanopterus, dan $C$. Spilopterus) selama tahun 2004 sampai dengan 2007 di perairan Indonesia. Hasil penelitian memperlihatkan bahwa ikan terbang (Excoetidae) memiliki peluang untuk memijah sepanjang tahun, dengan puncak pemijahan agak berbeda antar jenis maupun lokasi. Ada indikasi bahwa kecenderungan strategi pencapaian puncak pemijahan ikan terbang (Excoetidae) sangat dipengaruhi kondisi oseanografi, terutama suhu dan salinitas. Peristiwa upwelling yang secara periodik berlangsung selama musim timur (bulan Juni sampai dengan Agustus) di Laut Flores dan selatan Jawa diperkirakan sebagai faktor pemicu proses pemijahan ikan terbang (Excoetidae), sedangkan pola arus north equatorial di Laut Sulawesi sebagai faktor oseanografi yang mempengaruhi siklus reproduksi ikan terbang (Excoetidae). Pembuktian yang otentik lewat penelitian yang lebih komprehensif sangat diperlukan untuk mengungkapkan hal ini. Informasi ini akan sangat berguna untuk menyusun konsep kebijakan pengelolaan perikanan ikan terbang (Excoetidae) di Indonesia.
\end{abstract}

KATAKUNCI: reproduksi, ikan terbang, faktor oseanografi

ABSTRACT: Reproductive strategy of flyingfish (Exocoetidae) and its relationship with oceanographic factors in Indonesian waters. By: Augy Syahailatua, Syamsu Alam Ali, and Petrus Makatipu

Reproductive strategy of flyingfish (Exocoetidae) relate to like temperature, salinity, wind, rainfall, and solar radiation. Three species of flyingfish (Hirundichthys oxycephalus, Cheilopogon cyanopterus, and C. Spilopterus) had been observed from 2004 to 2007. The results show that those fishes spawn throughout a year, with the spawning peak differed slightly among species and locations. However, seemingly the spawning peaks associated to the oceanographic conditions, especially temperature and salinity. Reproductive strategic of flyingfish would be generated by decreased temperature. In Flores sea and south of Java, upwelling occurs during the southeast monsoon (June until August), and this event creates low temperature. Whereas in Sulawesi Sea, the decrease of sea surface temperature occurs due to the north equatorial current. A valid evidence from comprehensive study is required to proof the phenomena. This information is valuable to develop a management plan for flyingfish fishery in Indonesia.

\section{KEYWORDS: reproductive biology, flyingfish, oceanographic factors}

\section{PENDAHULUAN}

Ikan terbang (Excoetidae) dapat dikategorikan sebagai ikan pelagis kecil yang bernilai ekonomi, karena selain daging ikan yang dikonsumsi, juga telur merupakan komoditas ekspor penting. Tercatat ada 8 daerah memiliki produksi perikanan ikan terbang (Excoetidae) yang cukup signifikan, yaitu Sulawesi Selatan, Bali, Papua, Maluku, Nanggroe Aceh Darussalam, Nusa Tenggara Barat, Nusa Tenggara Timur, dan Sulawesi Utara (Tambunan, 2006). Sejauh ini hanya perikanan ikan terbang (Excoetidae) di Sulawesi Selatan yang sudah mencapai skala industri. Sasaran dari industri ini selain ikan terbang (Excoetidae) itu sendiri, juga telur-telur. Di daerah lain, komoditas ini terbatas hanya untuk memenuhi kebutuhan lokal. Dengan demikian, perikanan ikan terbang (Excoetidae) di Indonesia, seperti identik dengan Sulawesi Selatan, karena total produksi perikanan ini di Indonesia, didominasi oleh hasil tangkapan di wilayah Sulawesi Selatan, dengan ratarata produksi pada tahun 1998 sampai dengan 2004 mencapai lebih dari 34,8\% (Tambunan, 2006). Ini berarti, sentra utama perikanan ini berada di wilayah Sulawesi Selatan, terutama perairan Selat Makassar dan Laut Flores. Dalam kurun waktu 30 tahun terakhir, 
kondisi produksi perikanan ikan terbang di Sulawesi menurun drastis, dan kondisi yang sama juga dialami pada produksi telur.

Perburuan telur ikan terbang (Excoetidae) menjadi marak, karena komoditi perikanan ini memiliki harga jual yang tinggi. Namun sangat dikhawatirkan, eksploitasi telur ikan ini akan mempengaruhi stok perikanan. Indikasi penurunan produksi perikanan ikan terbang (Excoetidae), baik ikan dan telur dalam 2 dekade terakhir telah nampak (Syahailatua, 2006), sehingga langkah-langkah pengendalian perikanan ini sudah mulai dilaksanakan.

Terkait dengan usaha pengelolaan sumber daya perikanan ikan terbang (Excoetidae) yang lestari, maka serangkaian riset dikerjakan, termasuk riset aspek reproduksi ikan terbang (Excoetidae). Beberapa studi terdahulu tentang aspek reproduksi di perairan Selat Makassar dan Laut Flores telah dikaji untuk jenis H. oxycephalus (Nessa et al., 1977; Ali, 1981; Nessa et al., 1992), kemudian tahun 1990, aspek serupa juga dilaksanakan di perairan Saparua, Maluku (Peristiwady et al., 1991); dan di Majene, Sulawesi Barat (Andamari \& Zubaidi, 1994). Selanjutnya, sesudah tahun 2000, aspek reproduksi perikanan ikan terbang (Excoetidae) kembali dikaji untuk jenis $H$. oxycephalus di Selat Makassar (Ali, 2005), dan di perairan Binuangen (Jawa Barat) (Herawati et al., 2005), serta untuk jenis Cheilopogon cyanopterus dan
C. spilopterus di perairan Tahuna (Sulawesi Utara) (Makatipu \& Syahailatua, 2005).

Tulisan ini bertujuan untuk merangkum data dan informasi tentang tingkat perkembangan gonad dari beberapa jenis ikan terbang (Excoetidae) di perairan Indonesia, untuk mengungkapkan strategi reproduksi, khususnya musim pemijahan dalam kaitannya dengan kondisi oseanografi.

\section{BAHAN DAN METODE}

Data dan informasi yang dipergunakan merupakan hasil studi dari 3 jenis ikan terbang (Hirundichthys oxycephalus, Cheilopogon cyanopterus, dan $C$. spilopterus) di perairan Indonesia (Tabel 1, Gambar 1). Jenis $H$. oxycepahalus diperoleh dari Laut Flores dan perairan Binuangen, sedangkan $C$. cyanopterus dan C. spilopterus berasal dari Laut Sulawesi.

Seluruh contoh dikoleksi dengan jaring insang hanyut, dan dianalisis kondisi gonad di laboratorium. Penentuan tingkat kematangan gonad menurut kategori yang dimodifikasi oleh Effendi (1979); Lewis et al. (1962). Hasil penentuan tingkat kematangan gonad dipresentasikan dalam grafik (Gambar 2), dan perkiraan musim pemijahan dibuat berdasarkan pada besar persentasi dari tingkat kematangan gonad, terutama tingkat kematangan gonad IV di mana kondisi gonad siap memijah.

Table 1. Contoh 3 jenis ikan terbang (Excoetidae) yang diamati kondisi reproduksi selama tahun 2004 sampai dengan 2006

Table 1. Samples of 3 species flyingfish studied on reproductive condition in 2004 to 2006

\begin{tabular}{|c|c|c|c|c|}
\hline Jenis/Species & $\begin{array}{l}\text { Lokasi penelitian/ } \\
\text { Study sites }\end{array}$ & $\begin{array}{l}\text { Periode penelitian/ } \\
\text { Study period }\end{array}$ & $\begin{array}{c}\text { Jumlah contoh/ } \\
\text { No. of sample }\end{array}$ & Keterangan/Notes \\
\hline \multirow[t]{2}{*}{ H. oxycephalus } & Laut Flores & Maret-Juli 2004 & $Q=610, \partial^{\lambda}=647$ & Ali, 2005 \\
\hline & Binuangen & Juni-Sept 2005 & $\phi=76, \widehat{\partial}=166$ & Herawati et al. (2006) \\
\hline $\begin{array}{l}\text { C. cyanopterus } \\
\text { C. spilopterus }\end{array}$ & $\begin{array}{l}\text { Talaud } \\
\text { (Sulawesi Utara) }\end{array}$ & Jan-Sept 2005 & $\begin{array}{l}\hat{O}=138 \\
\hat{\theta}=197\end{array}$ & $\begin{array}{l}\text { Makatipu \& Syahailatua, } \\
2005\end{array}$ \\
\hline
\end{tabular}

\section{HASIL DAN BAHASAN}

\section{Hasil}

Pengamatan tingkat kematangan gonad dari ke-3 jenis ikan terbang (Excoetidae) ini disajikan dalam Gambar 2. Dari hasil ini dapat diprediksi musim pemijahan (Tabel 2). Nampak ada kesamaan periode pemijahan antar $H$. oxycephalus yang tertangkap di Laut Flores dan perairan Binuangen, yaitu antara bulan Juni sampai dengan Agustus, dengan puncak pemijahan pada bulan Juni. Sedangkan $C$. cyanopterus dan $C$. spilopterus di perairan Talaud memiliki periode pemijahan yang sama, namun memulai pemijahan lebih awal dari $H$. oxycephalus di
Laut Flores dan perairan Binuangen, yaitu bulan Pebruari dan berakhir bulan Juni.

\section{Bahasan}

Hasil kompilasi data tingkat kematangan gonad memperlihatkan ada sedikit perbedaan pada musim pemijahan antara lokasi pengamatan, yaitu perairan Binuangen dan Laut Flores berbeda dengan di Laut Sulawesi. Musim pemijahan ikan terbang $H$. oxycephalus di perairan Binuangen dan Laut Flores juga bersamaan dengan musim pemijahan ikan terbang (Excoetidae) di Selat Makassar (Nessa et al., 1977) dan di Laut Banda (Suwarso et al., 2008). Dengan demikian, diperkirakan musim pemijahan di 
perairan Binuangen, Laut Flores, Selat Makassar, dan Laut Banda sangat erat hubungannya dengan kejadian upwelling di Indonesia (Wyrki, 1961; 1962; llahude, 1978; Nontji, 2002). Sedangkan di Sulawesi Utara, musim pemijahan $C$. cyanopterus dan $C$. spilopterus sangat berkaitan dengan pola arus global di belahan utara Khatulistiwa (north equatorila current).

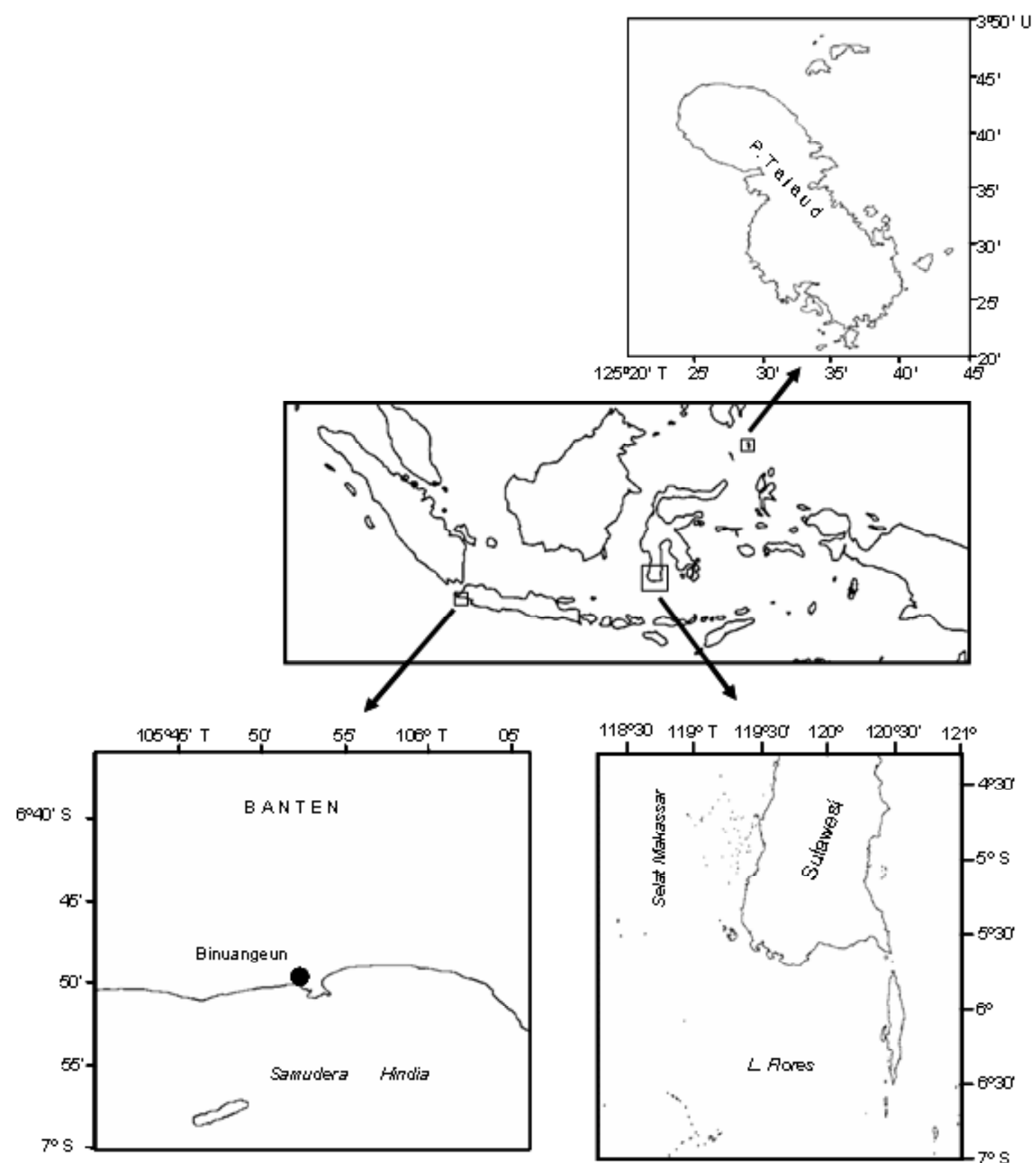

Gambar 1. Lokasi studi reproduksi biologi ikan terbang (Excoetidae) di Indonesia, selama tahun 2004 sampai dengan 2006.

Figure 1. Study sites of flyingfish (Excoetidae) reproductive biology during 2004 until 2006. 
a) H. oxycephalus, Perairan Binuangen

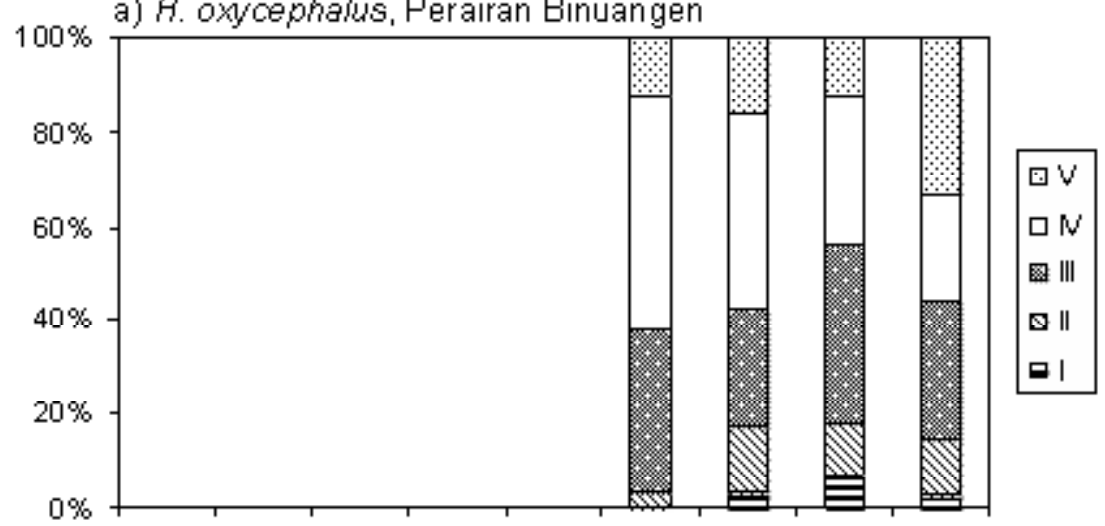

b) H. oxycephalus, Laut Flores
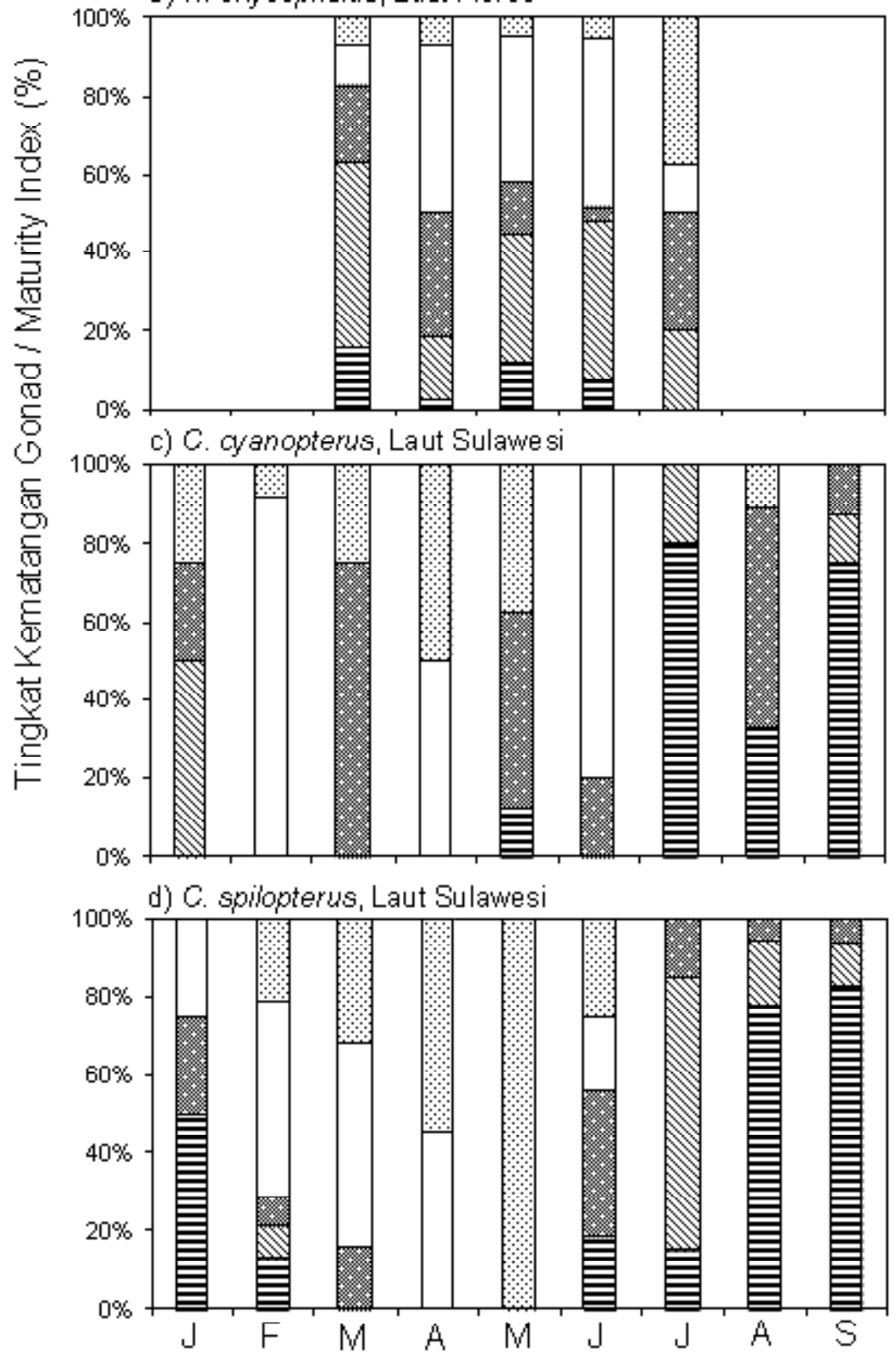

Gambar 2. Tingkat kematangan gonad (\%) ikan terbang (Excoetidae) dari 3 lokasi penelitian di Indonesia. Figure 2. Gonad maturity index of flyingfish (Excoetidae) from 3 study sites in Indonesia. 
Tabel 2. Ringkasan tingkat kematangan gonad ikan terbang (Excoetidae) (Gambar 2) Table 2. Summary of gonad maturity index of flyingfish (Excoetidae) (Figure 2)

\begin{tabular}{|c|c|c|c|c|c|c|c|c|c|c|c|}
\hline Lokasi/Location & Jenis/Species & $\begin{array}{c}\text { TKG/ } \\
\text { GM }\end{array}$ & Jan & Peb & Mar & Apr & Mei & Jun & Jul & Ags & Sep \\
\hline \multirow[t]{5}{*}{ Laut Flores } & H. oxycephalus & 1 & & & & & & 0,0 & 3,3 & 7,1 & 2,5 \\
\hline & & II & & & & & & 3,3 & 14,2 & 10,7 & 12,3 \\
\hline & & III & & & & & & 34,7 & 25,0 & 38,1 & 29,4 \\
\hline & & IV & & & & & & 50,2 & 41,7 & 32,1 & 22,9 \\
\hline & & $\mathrm{v}$ & & & & & & 11,8 & 15,8 & 11,9 & 33,0 \\
\hline \multirow[t]{5}{*}{ Binuangen } & H. oxycephalus & I & & & 15,4 & 2,8 & 12,1 & 7,7 & 0,0 & & \\
\hline & & II & & & 46,6 & 15,4 & 32,2 & 40,2 & 20,2 & & \\
\hline & & III & & & 19,4 & 31,5 & 13,4 & 3,9 & 29,9 & & \\
\hline & & IV & & & 10,0 & 43,0 & 37,1 & 42,8 & 12,3 & & \\
\hline & & $\mathrm{V}$ & & & 7,1 & 7,2 & 4,9 & 5,6 & 37,7 & & \\
\hline \multirow[t]{10}{*}{ Laut Sulawesi } & C. cyanopterus & 1 & 0,0 & 0,0 & 0,0 & 0,0 & 12,5 & 0,0 & 80,0 & 33,3 & 75,0 \\
\hline & & II & 50,0 & 0,0 & 0,0 & 0,0 & 0,0 & 0,0 & 20,0 & 0,0 & 12,5 \\
\hline & & III & 25,0 & 0,0 & 75,0 & 0,0 & 50,0 & 20,0 & 0,0 & 55,6 & 12,5 \\
\hline & & IV & 0,0 & 91,7 & 0,0 & 50,0 & 0,0 & 80,0 & 0,0 & 0,0 & 0,0 \\
\hline & & V & 25,0 & 8,3 & 25,0 & 50,0 & 37,5 & 0,0 & 0,0 & 11,1 & 0,0 \\
\hline & C. spilopterus & 1 & 50,0 & 13,2 & 0,0 & 0,0 & 0,0 & 18,8 & 15,4 & 77,8 & 82,4 \\
\hline & & ॥ & 0,0 & 7,9 & 0,0 & 0,0 & 0,0 & 0,0 & 69,2 & 16,7 & 11,8 \\
\hline & & III & 25,0 & 7,9 & 15,8 & 0,0 & 0,0 & 37,5 & 15,4 & 5,6 & 5,9 \\
\hline & & IV & 25,0 & 50,0 & 52,6 & 45,5 & 0,0 & 18,8 & 0,0 & 0,0 & 0,0 \\
\hline & & $\mathrm{V}$ & 0,0 & 21,1 & 31,6 & 54,5 & 100,0 & 25,0 & 0,0 & 0,0 & 0,0 \\
\hline
\end{tabular}

Keterangan: angka yang ditebalkan menunjukkan persentasi tertinggi setiap bulan/Bold indicates the highest monthly precentage

Kejadian upwelling adalah proses naik massa air dari lapisan dekat dasar ke lapisan permukaan perairan, dapat ditandai dengan penurunan suhu permukaan dan peningkatan salinitas. Bagi wilayah tropis seperti Indonesia, suhu permukaan pada $26^{\circ} \mathrm{C}$ dapat menjadi indikasi ada upwelling (Wyrtki, 1961; 1962; Ilahude, 1978; Nontji, 2002). Fenomena upwelling di perairan selatan Jawa dan Laut Flores terjadi antara bulan Juni sampai dengan Agustus (Wyrtki, 1961; llahude, 1978). Pada saat upwelling, kecepatan massa air yang dipindahkan $50 \times 10^{-5} \mathrm{~cm}$ per det di selatan Jawa (Wyrtki, 1962) dan di Laut Flores (llahude, 1978). Demikian juga, dengan peningkatan kandungan nutrien perairan, yang diindikasikan dengan konsentrasi komponen anorganik fosfat yang mencapai $0,8 \mu$ g.atom per I pada kedalaman 100 m di selatan Jawa (Wyrtki, 1962), sedangkan di Laut Flores pada permukaan konsentrasi fosfat 0,3 sampai dengan $0,5 \mu \mathrm{g}$ atom per I dan pada kedalaman 25 sampai dengan $50 \mathrm{~m}$ 0,6 sampai dengan $0,8 \mu \mathrm{g}$ atom per I (llahude, 1978).

Upwelling yang mengakibatkan pengayaan unsur hara di laut, memicu peningkatan produktivitas primer (fitoplankton) dan sekaligus produksivitas sekunder (zooplankton). Ikan yang memijah pada periode ini, larva ikan akan berpeluang memiliki asupan makanan yang memadai, dan akan berdampak pada kondisi larva ikan yang baik, sehingga menjadikan tingkat mortalitas larva ikan rendah, dan pada akhirnya rekruitmen dan stok perikanan menjadi baik (Syahailatua, 2004). Salah satu teori yang mendukung fenomena ini adalah match and mismatch yang diperkenalkan oleh Cushing (1990), yaitu larva ikan akan memiliki tingkat kesuksesan hidup yang tinggi bilamana larva tersebut berada di perairan yang memiliki cukup pasokan makanan, dalam hal ini zooplankton.

Pemijahan ikan terbang (Excoetidae) yang dikaitkan dengan proses upwelling juga sudah dikatakan dari beberapa lokasi lain, seperti di perairan Karibia (Ferbes-Ortega \& Harera, 1976; Gurthtsev et al., 1987), di Selat Makassar (Nessa et al., 1992), dan di Samudera Atlantik (Oxendford, 1994). Dengan demikian, strategi pemijahan ikan terbang (Excoetidae) yang dikaitkan dengan periode upwelling merupakan suatu fenomena yang dapat diduga dan telah dibuktikan.

Walaupun upwelling dianggap sebagai faktor dominan dalam kaitan dengan musim pemijahan ikan di laut, namun intensitas upwelling sangat berpengaruh terhadap keberhasilan rekruitmen ikan (Gambar 3, Cury \& Roy, 1989). Berdasarkan pada hasil kajian dari beberapa lokasi utama upwelling di dunia, rekruitmen maksimal terjadi pada saat upwelling dan kecepatan angin antara 5 sampai dengan $6 \mathrm{~m}$ per 
detik (Cury \& Roy, 1989). Kecepatan angin di Laut Flores pada periode bulan Juni sampai dengan Agustus diasumsikan sama dengan Laut Banda 6 sampai dengan $10 \mathrm{~m}$ per detik, namun ada variasi pada beberapa lokasi (Wyrtki, 1961), sehingga kondisi ini secara teori mendekati kondisi ideal untuk mencapai tingkatan rekruitmen ikan yang tertinggi.

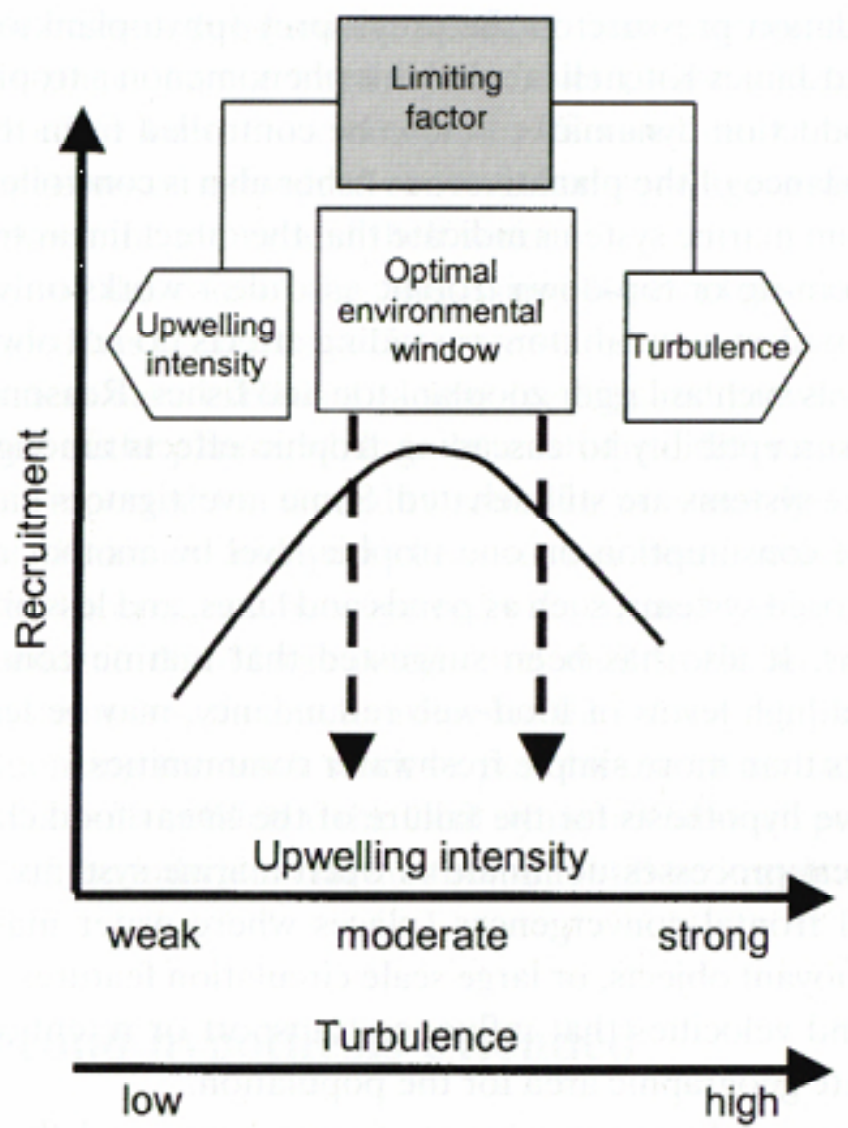

Gambar 3. Relasi antara intensitas upwelling dan turbulensi terhadap rekruitmen ikan. Sumber: Cury \& Roy (1989)

Figure 3. Relationship between upwelling intensity and turbulence, and recruitment levels of fish.

Sources: Cury \& Roy (1989)

Bagi Cheilopogon cyanopterus dan C. spilopterus di perairan Sulawesi, musim pemijahan mulai bulan Januari. Hal ini, terkait dengan fenomena oseanografi yang terjadi yaitu ada pasokan massa air dari Laut Cina Selatan, yang melewati Laut Sulu dan masuk ke Laut Sulawesi. Massa air ini menurunkan suhu permukaan perairan dan tercatat suhu permukaan terendah di Sulawesi Utara terjadi pada bulan Januari (Susanto et al., 2006). Hal ini, kemungkinan disebabkan oleh pengaruh pola arus north equatorial current yang membawa massa air bersuhu rendah akibat musim dingin di belahan bumi utara. Sebagai ikan pelagis yang wilayah hidup di lapisan permukaan, maka ikan terbang (Excoetidae) mengalami dampak dari penurunan suhu permukaan, yang sangat berpengaruhi pada sistem fisiologi ikan, sehingga memicu perkembangan gonad ikan terbang (Excoetidae), dan memijah.
Penurunan suhu dan musim pemijahan ikan juga diungkapkan dari hasil penelitian beberapa jenis ikan pelagis kecil di Teluk Ambon, seperti ikan teri atau puri, Stolephorus atau Encrasicolina spp. (Sumadhiharga, 1992), ikan layang, Decapterus (Sumadhiharga, 1991; Sumadhiharga, 1994), ikan tongkol (Auxis thazard thazard) (Sumadhiharga \& Langkosono, 1990), dan selar, Selaroides crumenopthalmus (Sumadhiharga \& Hukom, 1991). Puncak pemijahan dari 7 jenis ikan ini (Tabel 3), sebagian besar ( 6 jenis) terjadi pada periode bulan Mei sampai dengan Oktober, dan hal ini sangat terkait dengan periode upwelling dan penurunan suhu permukaan laut di Teluk Ambon. Proses upwelling di TelukAmbon berhubungan langsung dengan fenomena ini di Laut Banda, karena ke-2 kondisi perairan yang berdekatan dan merupakan laut dalam. 
Tabel 3. Perkiraan puncak pemijahan beberapa jenis ikan pelagis kecil di Teluk Ambon, Maluku Table 3. Prediction of spawning peaks of some pelagic species in Ambon Bay, Maluku

\begin{tabular}{|c|c|c|c|c|c|c|c|c|c|c|c|c|}
\hline Jenis/species & $\mathbf{J}$ & $\mathbf{F}$ & M & $\mathbf{A}$ & $\mathbf{M}$ & $\mathbf{J}$ & $\mathbf{J}$ & A & $\mathbf{S}$ & 0 & $\mathbf{N}$ & D \\
\hline Stolephorus bucanerii & & & & & & & * & * & * & * & & \\
\hline S. heterolobus & & & & & & & * & * & * & * & & \\
\hline S. devisi & & & & & & & * & * & * & * & & \\
\hline Decapterus ruselli & & & & * & & & & * & & & & * \\
\hline D. macrosoma & * & * & * & & & & & & & * & * & * \\
\hline Auxis thazard & & & & & * & * & * & * & & & & \\
\hline Selar crumenopthalmus & & & & & & * & & & & & & \\
\hline
\end{tabular}
(1992); Sumadhiharga (1994)

Proses pemijahan ikan pada saat suhu perairan rendah sangat beralasan, karena energi yang diperlukan ikan untuk metabolisme akan berkurang, sehingga simpanan energi tersebut dapat dipergunakan untuk proses kematangan gonad dan pelepasan telur atau sel sperma.

\section{KESIMPULAN}

1. Strategi pemijahan ikan terbang (Excoetidae) di Indonesia sangat terkait dengan kondisi oseanografi perairan. Dari bahasan di atas, terlihat bahwa musim pemijahan terjadi pada saat suhu permukaan menurun, bahkan mungkin mencapai suhu terendah dibandingkan dengan suhu permukaan rata-rata. Pemicu dari suhu permukaan rendah dapat berupa kejadian upwelling atau arus laut dari daerah berlintang tinggi (sub tropis atau kutub). Namun, nampak upwelling memiliki keeratan yang lebih kuat dari pola arus, karena selain menurunkan suhu permukaan, upwelling juga memperkaya unsur hara perairan, sehingga asupan pakan bagi larva dan ikan-ikan mudah akan terjamin.

2. Upwelling diperkirakan terjadi pada beberapa lokasi di Indonesia, namun belum banyak diinformasikan tentang mekanisme dari proses upwelling itu dan dampak yang ditimbulkan. Selama ini pemahaman yang berkembang bahwa lokasi upwelling sangat berpotensi sebagai daerah penangkapan ikan, namun dari banyak hasil studi di dunia yang mengatakan bahwa upwelling juga merupakan lokasi pemijahan ikan. Ke depan, diperlukan penelitian yang lebih komprehensif tentang kejadian upwelling dan juga fenomena oseanografi yang lain dalam kaitan dengan sumber daya perikanan.

\section{PERSANTUNAN}

Kegiatan dari hasil riset Kompetitif Lembaga IImu Pengetahuan Indonesia, Sub Program Sensus Biota Laut: Perikanan Ikan Terbang di Indonesia, Fokus Selat Makassar dan Laut Flores, T.A. 2004-2006.

\section{DAFTAR PUSTAKA}

Ali, S. A. 1981. Kebiasaan makanan pemijahan, hubungan panjang berat, dan faktor kondisi ikan terbang, Cypselurus oxycephalus (Bleeker) di Laut Flores Sulawesi Selatan. Tesis Pasca Sarjana Perikanan. Fakultas IImu-IImu Pertanian. Universitas Hasanuddin. Ujung Pandang. 45 hal.

Ali, S. A. 2005. Kondisi sediaan dan keragaman populasi ikan terbang, Hirundichthys oxycephalus (Bleeker, 1852) di Laut Flores dan Selat Makassar. Disertasi. Pascasarjana Universitas Hasanudin. Makassar.

Andamari, R. \& T. Zubaidi. 1994. Aspek reproduksi ikan terbang di Desa Rangas, Kabupaten Majene. Sulawesi Selatan. Jurnal Penelitian Perikanan Laut. 94. 11-22.

Cury P. \& C. Roy. 1989. Optimal environmental window and pelagic fish recruitment success in upwelling areas. Canadian Journal of Fisheries and Aquatic Sciences. 46. 670-680.

Cushing, D.H. 1990. Plankton production and year class strength in fish populations: An up date of the match or mismatch hypothesis. Advances in Marine Biology. 26. 250-293.

Effendie, M. I. 1979. Metode biologi perikanan. (Rev. Ed). Yayasan Dewi Sri. Bogor. vii+112 h. 
Ferbes-Ortega, G. \& L. E. Harera. 1976. Caribbean Sea circulation and water mass transport near the Lesser Antilles. Bol. Inst. Oceanographi University Oriente. 15. 83-96.

Gurdtsev, M. E., L. P. Salekhova, \& V. G. Lushchina. 1987. Distribution, ecology, and intraspecific variability of flyingfishes of the genus Exocoetus of the Atlantik Ocean. Journal Ichthyology. 27. 3950 .

Herawati L. M, M. Kamal, A. Djamali, \& A. Syahailatua. 2005. Biologi reproduksi Hirundichthys oxycephalus (Exocoetidae) di perairan Binuangaeun (Banten). Torani. Vol.15 (6) (edisi suplemen: ikan terbang). 369-379.

Ilahude, A. G. 1978. On the occurence of upwelling in southern Makassar Strait. Marine Research in Indonesia. $10.53 \mathrm{p}$.

Lewis, J. B., J. K. Brundritt, \& A. G. Fish. 1962. The biology of flyingfish, Hirundichthys affinis (Gunther). Bulletin Marine Science Gulf. Caribb. 12. 73-94.

Makatipu, P. C. \& A. Syahailatua. 2005. Faktor kondisi ikan terbang, Cheilopogon cyanopterus dan $C$. spilopterus dari perairan Tahuna, Sulawesi Utara 2005. Torani. Vol.15 (6) (edisi suplemen: ikan terbang). 380-386.

Nessa, M. N., H. Sugondo, I. Andarias, \& A. Rantetondok. 1977. Studi pendahuluan terhadap perikanan ikan terbang di Selat Makassar. Lontara. 13. 643-669.

Nessa, M. N., S. A. Ali, \& A. Rachman. 1992. Studi pendahuluan penetasan telur ikan terbang dalam rangka usaha pelestarian melalui restocking. Laporan Penelitian. Lembaga Penelitian Universitas Hasanuddin. Ujung Pandang. 70 hal.

Nontji, A. 2002. Laut Nusantara. Penerbit Jambatan. Jakarta.

Oxendford, H. A. 1994. Movements of flyingfish (Hirundichthys affinis) in the eastern Carribean. Bulletin Marine Science. 54. 49-62.

Peristiwady, T., A. Suwartana, \& S. Wouthuyzen. 1991. Beberapa aspek reproduksi ikan tuing-tuing (Cypselurus sp.) di Teluk Tuhaha, Saparua. Perairan Maluku dan Sekitarnya. 1991. 49-56.
Sumadhiharga, K. 1991. Struktur populasi dan reproduksi ikan momar merah (Decapterus russelli) di Teluk Ambon, perairan Maluku, dan sekitarnya. Balai Penelitian dan Pengembangan Sumber Daya Laut. P3O-Lembaga IImu Pengetahuan Indonesia. Ambon. 39-48.

Sumadhiharga, K. 1992. Anchovy fisheries and ecology with special reference to the reproductive biology of Stolephorus spp. in Ambon Bay, Indonesia. Ph. D. Thesis. University of Tokyo. Japan.

Sumadhiharga, K. 1994. Reproduksi dan makanan ikan momar putih (Decapterus macrosoma) di Teluk Ambon. Perairan Maluku dan Sekitarnya. Balai Penelitian dan Pengembangan Sumber Daya Laut. P30-Lembaga Ilmu Pengetahuan Indonesia. Ambon. Vol.6. 27-40.

Sumadhiharga, K. \& F. D. Hukom. 1991. Penelitian beberapa aspek biologi ikan kawalinya (Selar crumenopthalmus) di perairan Pulau Ambon dan sekitarnya. Perairan Maluku dan Sekitarnya. Balai Penelitian dan Pengembangan Sumber Daya Laut. P3O-Lembaga IImu Pengetahuan Indonesia. Ambon. 31-38.

Sumadhiharga, K. \& Langkosono. 1990. Beberapa aspek biologi ikan komo (Auxis thazard) di perairan Pulau Ambon, perairan Maluku, dan sekitarnya. Balai Penelitian dan Pengembangan Sumber Daya Laut. P3O-Lembaga IImu Pengetahuan Indonesia. Ambon. 28-36.

Susanto, R. D., T. S. Moore II, \& J. Marra. 2006. Ocean color variability in the Indonesian seas during the SeaWiFS era. Geochem. Geophys. Geosyst., 7. Q05021. doi. 10.1029/2005GC001009.

Suwarso, A. Zamroni, \& Wijopriyono. 2008. Eksploitasi sumber daya ikan terbang (Famili Exocoetidae) di perairan Papua Barat. Bawal. [in press].

Syahailatua, A. 2004. Larva ikan sehat, stok ikan kuat; Kompas, Rabu 4 Februari 2004. Hal.28.

Syahailatua, A. 2006. Perikanan ikan terbang di Indonesia: Riset menuju Pengelolaan. Oseana. Vol. XXXI (No.3). 21-31.

Tambunan, P. 2006. Beberapa informasi tentang ikan terbang di Indonesia. Dalam: Omar et al. (eds), Prosiding Lokakarya Nasional Perikanan Ikan 
Terbang. Makassar, 20-21 September 2005. Hal. 9-15.

Wyrtki, K. 1961. Physical oceanography of the southeast Asian Waters. Naga Report. Vol.2. Scrippts Inst. Oceanography. California.
Wyrtky, K. 1962. The upwelling in the region between Java and Australia during the southeast Asia monsoon. Australia Journal Marine Freshwater Resources. 13. (3). 217-225. 